\title{
Language In Political Discourse: A Pragmatic Study Of Presupposition And Politeness In The Inaugural Speech Of President Donald Trump
}

\author{
Balogun, Sarah \\ Department of English, Federal College of Education, Zaria, Kaduna State, Nigeria \\ sarafinabally@gmail.com \\ Murana, Muniru Oladayo \\ Department of European Languages, Federal University Birnin-Kebbi, Kebbi State, Nigeria \\ muranamuniru1@gmail.com
}

\begin{abstract}
Inauguration ceremony of a new president is likely a common ritual the world over. It is an observance that constitutes the formal investiture for the president. Inaugural speech is central to the rites of inauguration and it is usually anticipated for the soothing promises it makes and the reassurances it contains. This study investigates pragmatic presuppositions made and politeness strategies employed by President Donald Trump in the speech delivered at his inauguration ceremony. The text of the speech is downloaded from the net to ensure accuracy and the ninety-nine (99) sentences in it numbered serially for ease of reference and close analysis. The study reveals that Trump presupposes among others the uniqueness of the event, the socio-economic crisis bedevilling America and the imperative and urgency of the need to salvage her. Regarding politeness, the paper unravels both the face saving and face threatening acts performed by the speaker and the various strategies deployed. It concludes that although Trump strives hard to mitigate the threats to the face of the past American leaders among others, the poignancies of the threat still remain painfully memorable for their enormity and emphasis.
\end{abstract}

Keywords: Donald Trump, Inaugural Speech, Presupposition, Politeness.

\section{Introduction}

Speech delivery by the newly elected president is a major aspect of the inauguration ceremony. Such an inaugural speech is delivered amidst fanfare, jubilation and renewed hope for a better future. A presidential speech is therefore unique in a number of ways. Although a political speech, it is delivered at an interval of some years, most often four years. It has both national and international implications and so listeners to it essentially cross borders. Inaugural speech is a victory speech; it makes the reality of the success of the new president felt and more so by the people of the opposition party or parties and consequently marks the beginning of their compulsory acceptance and submission. It is in a way the linguistic beginning and legislation of a social-political and ideological era.

America occupies a pride of place in the political topography of the world and her actions and inactions attract international attention. The president of America is perceived in some quarters in this connection as the president of the world. This background makes the inaugural speech of an American president very important, widely anticipated, collectively heard and variously interpreted. The logical expectation, considering the enviable place of America in world affairs and politics is that her president employs tact in national and international discourse to keep both the Americans and the globe at peace.

Human beings are naturally classed. People relate in groups as kin, folks, kiths, mates, adherents and so on. It is, therefore, natural that human linguistic behaviour reflects these groupings 
by lexicalising or grammaticalizing inclusion and exclusion. But the fact that all such groups are mere co- hyponyms of the single class, human - the superodinate - presupposes the need for great caution in the exercise of the linguistic and communicative rights of members of the subgroups. This is the realm of tact and politeness in showing distance and closeness which are basic to pragmatics. Donald Trump is known prior his election especially through his volatile electioneering campaigns and activities on social media for his bluntness and excessive directness. His success in the election shows that, to the majority of the Americans, this is a minor factor. Trump's sharp language which finds accompaniment in his hard look is, however a source of concern for some Americans and other nations of the world.

This paper investigates the nature of presupposition and politeness in the inaugural speech of Donald Trump to serve as an empirical base for defining his linguistic behaviour and assessing the concern of his critics.

\section{Literature Review}

\section{Language of Politics}

The bond between language and politics is derivable from the association of language and communication. Man is a political being whose entire life is permeated by politics and his blessing of speech provides apt enablement. Language plays a crucial role in politics as every political action is prepared, accompanied, controlled and influenced by it (Schaffer, 1996). The importance of the study of language of politics, according to Beard (2000) is to know how language is utilized by those who desire to gain, exercise and keep power. Language is used in politics to make speeches and remarks. Thus, political career is negotiated, secured and practised through the instrumentality of language whose product, in this wise is mainly speech making. Beard (ibid: 35) further adds that "making speeches is a vital part of the politicians' role in announcing policies and persuading people".

Lakoff (1990:7) presents the inextricable relationship between language and politics more aptly. He posits that "language is politics, politics assigns power, and power governs how people talk and how they are understood". He notes further that political manipulations depend on the use of language because language initiates and interprets power relations. Thus, language serves to bestow or confer power and delineates the relationship among its users through the roles it allots to them. Power is demonstrated through the use of language and every language user "plays the linguistic power game according to hidden agendas, the unsaid being far more potent than the said" (ibid :21). The clarification of the unstated meaning or the 'hidden agenda' is the concern of pragmatics (Mey, 2001:207).

It is language that provides the opportunity for politicians to explore its verbal communicative resources and manipulate words to suit their intentions. Hence, language could be regarded as the vehicle of politics. In this direction, Opeibi (2009) points out that language is the channel for the expression of the candidate's manifesto, superior political thoughts and party's ideologies and it is the tool for translating them into social actions for social change and continuity. Therefore, the place of language in convincing, mobilising, persuading and enlightening the citizenry cannot be over emphasized. It is the link to people's hearts. Akinkurolere's (2011) argument that the support politicians enjoy from the citizens is predicated upon their message and the manner of presentation is apt as these determine success of candidacy, programmes or policies. Both the political message and its manner of presentation are consequently very important. For this reason, the study of political discourse has been carried out through the related frame works of discourse analysis, stylistics, rhetoric and pragmatics. Two resources of pragmatics are employed for analysis in this paper. 


\section{Pragmatics}

The various definitions of pragmatics available in the literature point at its emphasis on the primacy of context for a meaningful interpretation of language in use. Pragmatics, according to Leech (1981) investigates the aspect of meaning derivable from the manner in which utterances are used and how such utterances relate to the context of their use. This view regards pragmatics as a theory of appropriateness in any discourse. Lawal (2003:150) defines pragmatics as "the study of how context influences our interpretation of utterances." Pragmatic analysis of language according to Adegbija (1999:189) is an investigation of "how language is used in any particular communicative contexts or situations". Yule (1996:3) similarly provides four interrelated aspects of the definition and scope of pragmatics as; the study of speaker meaning; the study of contextual meaning; the study of how more meaning get communicated than said; and the study of expression of relative distance. Thus, the concern of pragmatists includes the interractants, the context, the unsaid or meaning communicated and its implication in discourse. This informs Allan's (1986) definition of pragmatics simply as the study of interactional meaning. Pragmatics, to unravel interactional meaning, includes in its scope such aspects as: context, speech acts, deixis, conversational principle, politeness, presupposition among other concepts concerned with basics and nuances of communicative values. Interactional meaning specifically in inaugural speeches has been the focus of many studies.

Murana (2011) examines the dimension of interaction in Barrack Obama's inaugural speech. It is a mood analysis predicated on the interpersonal metafunction of the Hallidayan Grammar to unravel role relationship, speech acts and politeness strategies in the address. The paper reveals the basis for the ambiguous nature of speeches in terms of their being both spoken and written texts. It shows through the analysis of mood and modality in the speech that Obama assumes the roles of a democratic leader, an optimistic adviser and motivator and a humble but stern commander while he assigns such roles as active led, wise advisees, potential team workers to his listeners.

Ayeomoni and Akinkulere (2012) study President Musa Yar'adua's victory and inaugural speeches through the frame work of the speech act theory of Austin (1962) and Searle (1969). The study focuses on the triad of locutionary, illocutionary and perlocutionary acts in the speeches and analyses their pragmatic patterns. The paper finds that although Yar'adua performs speech acts such as assertives, directives, expressives, verdictives, commisives and declaratives, assertives are more prominent in the speeches.

Abuya (2012) similarly carries out an analysis of President Goodluck Jonathan's inaugural speech from a pragma-stylistic perspective with a view to describing the linguistic acts in the speech. Using the speech act theory of Austin (1962) and Searle (1969), the study also focuses on the locutionary, illocutionary and perlocutionary acts in the speech. The study reveals that President Jonathan's inaugural speech contains assertive, verdictive, commisive and declarative acts, although it features more commissive acts than others.

Balogun (2015) investigates parallelism in the speeches of President Goodluck Jonathan and President Barack Obama using Davy and Crystal's (1969) stylistic theory. It is a comparative stylistic study that reveals the manner of emphasis and foregrounding in the interactions. The study finds that parallelism is more aesthetically used by President Obama than President Jonathan and consequently argues that the speakers varied levels of exposure to the language is hugely responsible for the disparity. The study also finds that repetition plays a significant role in creating foregrounding effects in the speeches of both presidents.

These various studies are pragmatic in their foci especially with common interest in interactive discourse and emphasis on speech acts. This paper is equally interested in inaugural speech but its foci are different. It attempts to reveal the various assumptions made by the speaker in his presentation of the common experience to him and his varied listeners as well as the face work undertaken by him while keeping his distance and at the same time ensuring compliance with the 
human social expectation of politeness. Therefore, its specific frame work is a combination of presupposition and politeness.

\section{Theoretical Framework: Presupposition and Politeness}

\section{Presupposition}

Yule (1996:25) defines presupposition as "something the speaker assumes to be the case prior making an utterance." The speakers, according to him, not the sentences, have presuppositions. It is, thus, a premise or ground assumed by the speaker in relation to the hearer's knowledge. Presupposition is "the explicit assumption about the real world which speakers make and on which the meaning of an utterance largely depends" (Lawal, 2003:153). Speakers or writers usually design their message on the assumption that the hearer or reader already has a degree of the knowledge of what is being communicated. The presupposed knowledge is naturally taken for granted as it believed that the listener or reader will understand the communication by processing the said with the shared information about the subject and the context.

As Grundy (2000) points out, certain clauses are employed to make presuppositions because of some words that they contain. Such words express change of state predicate like begin and continue or time such as after and before. Yule (1996) similarly notes that certain forms - words, phrases and structures - have been associated with the expression of presupposition. He identifies types of presupposition as: (i) existential (expressed through possessive forms or noun phrases), (ii) factive (expressed by words signifying fact), (iii) lexical (expressed through the non assertive meaning of words), (iv) structural (expressed through certain grammatical constructions), (v) nonfactive (expressed to show that something is false) and (vi) counter-factive (expressed through structures used to show unreality). Presupposition is natural in interaction as it helps the speaker to predicate his/her speech on common knowledge and helps the hearer also to make inferences.

\section{Politeness}

Part of the political nature of man is his innate sense of dignity or self-importance that he wants others to acknowledge. This is the sense to be regarded and treated as human. Grundy (2000: 147) describes linguistic politeness as "the function of language to imply the most appropriate speaker-hearer relationship". Appropriateness in this regards essentially involves a lot of linguistic considerations to effect and maintain acceptable interpersonal relationship. Politeness is a means of avoiding conflicts and establishing harmonious interpersonal relationship between social interractants (Izadi, 2013). Communication involves doing things with words or performing speech acts (Austin, 1961) and the exercise of caution in the performance of acts not to avoidably hurt the feelings of others is called politeness. Brown and Levinson (1987) underline the use of indirect speech act as a feature of politeness and further relate politeness to face which they describe as "the public self image that every individual wants to claim for himself." They identify two types of face as: positive face, "the individual's want of admiration and approval" and negative face, "the individual's want of freedom from imposition" (ibid: 67). Similarly, Yule (1985: 134) describes politeness as "showing awareness of another person's face.

Some speech acts have intrinsic threat in them; they are Face Threatening Acts (FTA's) while certain acts are performed to lessen the possible threat to face; these are Face Saving Acts (FSA's). Both positive and negative face types are constantly at the risk of being threatened and as a result conscious interractants usually strive to save them in communication. FSA's are achieved through mitigation, which involves employing such politeness strategies as indirection, hedges, deference, apology, generalization and nominalization among others (Brown and Levinson, 1987). The nature of texts however determines both the kinds of acts, the prevalence or otherwise of FTAs and the appropriate politeness strategies. 
Presidential inaugural speech as a genre is characterized by the clear distance between its president-audience participants. The president is the speaker and the listeners or audience include the citizens, one or more of who might be the formal presidents and non-citizens. Besides, there is inequality in terms of the power relation between the speaker and the audience. These demand a great deal of face work on the part of the president who will need to articulate his unique mission and achieve solidarity and peace.

\section{Analysis of the Speech}

The inaugural speech of the $45^{\text {th }}$ president of the United States of America, President Donald Trump is composed of ninety-five (99) sentences which are largely structurally simple. Perhaps, this is a linguistic reflection of his promise to be of more actions and less speech. The sentences (scs) are numbered serially for easy of reference in the analysis. The speaker's assumptions about the reality of America and his attitude to smooth interpersonal relationship as reflected in the speech are analyzed under the two headings: Presuppositions in the Speech, and Politeness Strategies Employed in the Address

\section{Presuppositions in the Speech}

In an inaugural speech of this nature, presupposition is a measure of the way the speaker characterizes his listeners' knowledge about themselves, their affairs and the general state of the nation. Donald Trump's speech reveals five (5) areas of knowledge of common reality he believes his listeners, especially the Americans, share with him and on which there is no argument and therefore part of the bases for his election.

The uniqueness of the event and invariably the speaker is significantly presupposed. The knowledge of this is taken for granted and thereby presented as indubitable in a number of ways. The speaker achieves this presupposition particularly in four sentences - scs: 1, 8, 25 and 44. The first of these sentences for this purpose appreciates rather than greets as it is typical.

\section{Chief Justice Roberts, President Carter, President Clinton, President Bush, President Obama, fellow Americans and people of the world, thank you. (sc 1) Today's ceremony, however, has very special meaning...we are transferring power back to you, the people. (sc 8) \\ You came by the tens of millions to become part of a historic movement, the likes of which the world has never seen before. (sc 25) \\ We assembled ... are issuing a new decree to be heard in every city \\ In every foreign capital and in every hall of power (sc 44)}

The speaker's presupposition in the first sentence is that his audience is peopled by everybody: the past American presidents, the American citizens and the whole world. In the next, sentence 8, he crystallizes the knowledge of the uniqueness of the occasion emphasising his and his audience's belief that the ceremony has special meaning while its unprecedented nature is passed as common knowledge in the expression the like of which the world has never seen before (sc 25). This same presupposition is consolidated with the reference to the varied listeners in every city, foreign capitals and every hall of power (sc 44). The various names of dignitaries as well as distant places referred are existential presupposition which the speaker has.

Next in their order of presentation but most important to the speaker is his assumption that The listeners know that America is in socio-economic crisis and has therefore lost her glory. This presupposition is obvious first in the second sentence of the speech and it is particularly signalled lexically by the two words: rebuild and restore in:

We the citizens of America are now joined in a great national effort to rebuild our country and restore its promise for all of our people (sc 2) 
Through the morphology of the two words, that America has lost its old worth is communicated by the speaker as a common knowledge. The new president believes that nobody would wonder why America needs to be rebuilt or restored since its structural and economic degeneration is a common knowledge.

Again, the Americans are believed by Donald Trump to have known the source of the relapse to be a small group among them who have consistently denied others of the supposedly common opportunity. Both the knowledge of the loss and the agents of denial are communicated as common through structural parallelism, adversative (but) and negator (not) in the next excerpt:

Washington flourished, but the people did not share in its wealth. Politician prospered, but the job left and the factories closed.

The establishment protected itself, but not the citizens of our country.

Their victories have not been your victories.

Their triumphs have not been your triumphs. (scs 10-14)

Thus, Trump presupposes the current state of America as a product of misrule and selfishness which he encodes as common knowledge through juxtapositions of their political achievement and national needs. Similarly, He underlines the general assumption underlying the poor performance of his predecessors in such structural description as all talk and no action (sc 74) and people of empty talk (sc 75)

In communicating the knowledge of America's degeneration as a reality to him and other Americans, Trump repeatedly employs again in the following excerpt:

\section{Together, we will make America strong again. We will make America wealthy again. We will make America proud again. We will make America safe again.}

And yes, together we will make America great again. (scs 90-94)

The speaker's repetition of again in the five consecutive sentences above reveals his belief that his American listeners if not all his listeners know that America was once strong, wealthy, proud, safe and great. The promises contained in the sentences are consequently apt and warranted by the shared national and international knowledge that America is currently weak, poor and unsafe.

As a logical sequel to his assumption of America's degeneration, Trumps presupposes that everyone knows that change is inevitable to restore the glory. This knowledge can be adduced as the rational for his election. The following sentences in the speech will be questionable without such an assumption:

\section{That all changes starting right here and right now because this moment is your moment, it belongs to you. (sc 16)}

From this day forward, a new vision will govern our land. (sc 45)

The urgency of the changes required as well as the preparedness of the speaker is communicated through adverbials: right here, right now (sc 16) and from this day (sc 45) and the noun phrase: this moment (sc 45). Besides, with starting (16), Trump presupposes the unprecedented nature of his action plan. He further underlines what he takes to be collectively assumed pitiable reality against which his government is expected to work in his consecutive repetition of the phrase: will bring back in sentences 52 to 55 . The lost values are expected to be restored. The speaker's willingness is expressed by the modal will while the remaining part of the verb phrase, bring back, reveals his assumptions of the common knowledge and aspiration of the need for change oriented actions.

One more important presupposition had by the president expectedly is the common knowledge of some existing development. This is logical since it will be unacceptable to his listeners that his government is starting everything afresh. Thus, in spite of his stress on the ineptitude, egocentricity and talkativeness of the past leaders, certain developments which can be consolidated have been achieved by them. This he presupposes through: 


\section{We will build new roads and highways and bridges and airport}

and tunnels and railways all across our wonderful nation (sc 56)

The lexical presupposition obvious in the choice of new in the first line of the above sentence is that old ones of the various facilities promised exist in America. This is a major way to balance the sharp criticism of the American politicians and the common reality of America as shared by all.

\section{Politeness Strategies in the Address}

The task of governance though often vested on a group of people is a collective responsibility if it must be successful. The speech of a new president is to formally initiate this duty. Thus, as a communicative event, an inaugural speech normally features promises or reassurances by the president as well as call or request for support of the citizenry and other nations. There is a major role relationship of the leader (the president) and the lead (the citizens). Among the citizens, however, are some socially special people. These may include the ex-presidents, the defeated presidential contestant(s) and other important dignitaries. The composition of the audience nationally is complex and so is the nature of the distance. Again, there is the secondary role relationship of foreign president and foreign audience. The two, though distanced by space belong to the same globe and are involved in the discourse. The foreign audience is peopled by men and women of varied statuses, colours and races. As a sequel to the foregoing, the speech needs to aptly present the vision and or mission of the new government and deftly safe the face of the listeners to whom references may be made in it. Politeness is, therefore, requisite in ensuring fairness in the task. Trump's efforts in this direction are discussed in the next two subheadings

\section{Face Saving Acts}

The speech reflects premeditated face saving acts in spite of the biting criticism it contains. The speaker's consciousness of the importance of saving the face of his varied listeners and avoiding or at least limiting face threatening acts is asserted in his following words:

We will seek friendship and good will with the nations of the world... (sc 59)

We do not seek to impose our ways of life on anyone... (sc 60)

We will reinforce old alliances and form new ones... (sc 62)

Mr President's declaration of his government's promise to partner with other nations underscores his knowledge of the place of international cooperation in achieving America's progress. It is a promise of recognition and an appreciation of collectivism. Besides his crave for alliance which defines a positive face saving act, his declaration of his administration's intention to avoid imposition is a testimony to his consciousness of the need not to threaten the international listeners' negative face. The two pledges satisfy the requirements of both positive and negative politeness.

The speech begins on a note of appreciation and praise which are invariably a mark of recognition and a call for support. The expression thank you in the first sentence of the address enacts a polite recognition of the presence of the Chief Justice Roberts, the four past American presidents, the Americans and finally the people of the globe. The appreciation begins from the specific to the general. Expectedly, Trump more specifically appreciates his predecessor and his wife - President Obama and First Lady Michelle Obama - for their role in the transition process as follow:

\section{They have been magnificent.}

\section{Thank you. (scs 6-7)}

This is certainly pleasing to the outgoing president, his wife and listeners who believe that Obama did his best during his tenure. In three other sentences $-7,95$ and 98 the same expression of appreciation, thank you, is reiterated to show gratitude to the listeners generally to give them recognition and make them feel valued in line with their own estimation of their self-worth.

The speech also features devices of inclusion which are prerequisites for achieving positive politeness. The first person plural we is employed to foreground the speaker's crave for support and perception of his American audience as active stakeholders in achieving the change that America 
deserves. He, therefore, represents the audience as important through the audience inclusive pronoun chosen. Remarkable among the occurrences of this pronoun are the ones found in the following part of the speech:

\section{Together we will determine the course of America... (sc3) \\ Together we will make America great again. (sc 90) \\ And yes, together we will make America great again (sc 94)}

Both the pronoun we and the adverb together preceding it in each of the sentences above are face devices employ to match the Americans' opinion about their role in ensuring better America. The same reason explains the rare occurrence of the first person singular pronoun I in the text. Only in two sentences ( 35 and 50 ) in the whole of the speech can it be found.

Similarly, the second person plural pronoun you and its derivative your are used in introducing a dimension of deference to the speech. Trump humbles himself and ascribes his victory to his American audience as shown in back to you (sc8); belong to you (sc16), your day (sc 18), your celebration (sc 19), your country (sc 20) and listening to you (sc 24). The speaker through this means distances himself from his feat to honour the citizens. This is perhaps the peak of his face work in the address.

\section{Face Threatening Acts}

Although the speech as shown above consists of varied face saving attempts made by the speaker especially through such speech acts as appreciation, recognition and inclusion, it features a lot of criticisms which according to Levinson (1987) are intrinsically face threatening acts. At some point the criticisms translate into poignant accusations. Perhaps the speaker's reason is to justify his election and stress his capability and readiness to propel a positive and unprecedented change. But this is unwarranted especially on this particular occasion. Unarguably, face threatening acts are natural in some contexts even though they are detestable. It is doubtful, however, if they are quite appropriate especially as enormous as they are in this context. Threatening the face of social equals and dignitaries who have made selfless contributions to common course is not desirable.

Conscious of this fact, Trumps again annexes the flexibility of the third person plural pronoun we to generalize his criticism of the previous American governments as general failure of the Americans. The following excerpt exemplifies this strategy:

We've defended other nations' boarders while refusing to defend our own.

And (we have) spent trillions overseas while America's infrastructure has fallen into disrepair and decay.

We've made other countries rich, while the wealth, strength and confidence of our country has dissipate over the horizon.(scs37-39).

The portrayal of the previous administrations as inept as well as the condemnation implied is lessened by the speaker inclusive we repeatedly used. It would be totally inexcusable to use you in place of we in the extract.

Apart from mitigating the obvious threat posed to the previous American leaders in attendance by the speech act of criticism and or condemnation as shown above, Trump also employs the device of indirection in lambasting them as egocentric and selfish as evident in his reference to the accused leaders by the parallel nouns / noun phrases: a small group (sc 9), Washington(sc 10), politicians (sc11) and the establishment (sc 12) used consecutively to avoid a specific mention of the names of the individuals sitting before him or their regimes. Indirection is achieved in different ways in the cited phrase. It is achieved through the indefinite article a in a small group, through partwhole generalization in Washington and via vagueness in politician and establishment.

The speaker equally indicts his immediate predecessor and other past leaders of America of mismanagement of the national resources over the years. He strives to mitigate this through personification and agent-less passive as shown below:

One by one, the factories shuttered and left our shores... The wealth of our middle class has been ripped from their homes... (sc 40-41) 
In the first sentence, the companies are personified and representatively accused of both inactivity and departure to save the threatened face of the administrators while the rippers are neither mentioned as subject or agent in the second sentence. The two devices are appropriate in reducing the threat and making it moderately bearable.

A fairly understandable face threatening act in the speech targeted at summoning courage in the American audience is performed through imperative sentences. For its tendency to impose, an imperative statement is inherently face threatening in its orientation. Imposition is contained in the warning issued to the audience in:

Do not allow any anyone to tell you that it cannot be done (sc 77)

Trump's assumes the role of an adviser warning adults like him against the cynics. His mission to make them optimistic of his ability to deliver on his promise contravenes their self desire for independent thought. Similarly threat is included in there should be no fear (sc 68) and we must think big and even dream bigger (sc 72). The fact is that every rational adult holds an opinion on issue that affects him or her based on experience, ideology, premonition and so on.

The threat to face in the address extends to the international community. Trump characterizes some countries of the world as ravagers, destroyers and thieves in:

\section{We must protect our boarders from the ravages of other countries making our products, stealing our companies and destroying our jobs. (sc 48)}

This reference is defamatory, nauseating and face threatening. Although the referred nations are not specifically mentioned in this case, Trump's subsequent promise to eradicate radical Islamic terrorism from the face of the Earth (sc 62) provides an insight. This delimitation shows a threat against the Muslim world and a religious bigotry.

\section{Conclusion}

Inaugural speech as a form of discourse offers elected public office holders the opportunity to make promises and to give assurance of good governance through effective language use. Through the analyzed speech, Trump makes a lot of presuppositions to demonstrate his vast knowledge of the Americans and current socio-political realities of the United States of America. The presuppositions serve as premise for the various promises he makes. They also account for the prevalence of structurally simple sentences through which he draws on the shared knowledge of his American listeners without boring details. Trump also embarks on a lot of face work asserting lucidly the essence of collectivism and the evil of imposition. The speech, however, conspicuously include ample avoidable face threats occasioned primarily by extensive criticism and accusation. The hedges employed to mitigate the shock associated with his criticism though make them unavoidably bearable but still sadly memorable. This confirms his critics 'argument that he is vulgar.

\section{References}

[1] E. J. Abuya (2012). 'A Pragma-stylistic analysis of President Goodluck Ebele Jonathan's inaugural Speech.' in English Language Teaching. Canadian Center of Science and Education .5 No.( 11$)$.

[2] E. E. Adegbija, (1999). 'Titbit on discourse analysis and pragmatics.' E. Adegbija (Ed.) The

[3] English language and literature in English. An introductory handbook. Ilorin: Department of MEL, University of Ilorin, pp. 189-202.

[4] S. O. Akinkurolere, (2011). 'A speech act analysis of selected political speeches of President

[5] Umaru Musa Yar'adua'. An Unpublished M. A. Thesis of Department of English, Obafemi Awolowo University, Ile Ife.

[6] K. Allan, (1986). Linguistics meaning. Vols 1 \& 11. London: Rutledge and Kegan Paul.

[7] J. L. Austin, (1962). How to do things with words. London: Oxford University Press. 
[8] O.M. Ayeomoni and S.O. Akinkuolere, (2012). "A pragmatic analysis of victory and inaugural speeches of President Umaru Musa Yar'Adua”. Theory and Practice in Language Studies 2 (3) 461-468.

[9] S. Balogun, (2015). A linguistic stylistic analysis of parallelism in inaugural speeches of presidents Barrack Obama and Goodluck Jonathan. An unpublished Master's Thesis of the Department of English, Ahmadu BelloUnviersity, Zaria.

[10] E. Barton, (1990). Non-sentential constituents: A theory of pragmatics and grammatical structure. New York: John Benjamins Inc.

[11] A. Beard, (2000). The language of politics. London: Rutledge.

[12] P. Brown, and Levinson, S. (1987). Politeness phenomena: Some universals in language use.Cambridge: Cambridge University Press.

[13] P. Grundy, (2000). Doing pragmatics. 2nd Ed. London: Arnold

[14] A. Izadi, (2013). 'Politeness in spoken review genre: Viva Voce Context.' PERTANIKA, Journal of Social Sciences and Humanity. 21 (4) pp.1411-1430

[15] http://www.pertanika.upm.edu.my/ Journal of Social Sciences.

[16] R. Lakoff, (1990). Talking power. Basic Books.

[17] R.A. Lawal, (2003). "Pragmatics in stylistics: A speech act analysis of Soyinka's 'Telephone Conversation'. In A. Lawal (Ed.) Stylistics in theory and practice. Ilorin: Paragon Books.

[18] G. Leech, (1983). Principles of pragmatics. New York: Longman Inc.

[19] J. L. Mey, (1993). Pragmatics. Oxford: Blackwell Publishers

[20] M.O. Murana, (2011). 'The dimension of interaction in public speeches: A mood analysis of President Obama's inaugural speech'. Papers in English and Linguistics (PEL). OAU, Ile-Ife. Pp 230-46

[21] B.O. Opeibi, (2009). Discourse, politics and the 1993 presidential election campaigns in Nigeria Lagos: Nouvele Communications Limited.

[22] C. Schaffner, (1996). 'Editorial: Political speeches and discourse analysis.' Current Issues in

[23] Language and Society. 3 (3) http://pdfserve.informaworld.com/

[24] J. R. Searle, (1969). Speech acts: An essay in the philosophy of language. Cambridge: CU

[25] R. Taiwo, (2009). "Legitimization and coercion in political discourse: A case study of Olusegun Obasanjo's address to the PDP elders and stakeholders forum". Journal of Political Discourse Analysis. 2 (2) pp.191-205.

[26] G. Yule, (1985).The study of language. Cambridge: Cambridge University Press.

[27] G. Yule, (1996). Pragmatics. Oxford: Oxford University Press 


\section{Appendix}

\section{President Donald Trump's Inaugural Address}

[1] Chief Justice Roberts, President Carter, President Clinton, President Bush, President Obama, fellow Americans and people of the world, thank you.

[2] We, the citizens of America, are now joined in a great national effort to rebuild our country and restore its promise for all of our people.

[3] Together, we will determine the course of America and the world for many, many years to come.

[4] We will face challenges, we will confront hardships, but we will get the job done.

[5] Every four years, we gather on these steps to carry out the orderly and peaceful transfer of power, and we are grateful to President Obama and First Lady Michelle Obama for their gracious aid throughout this transition.

[6] They have been magnificent.

[7] Thank you.

[8] Today's ceremony, however, has very special meaning because today, we are not merely transferring power from one administration to another or from one party to another, but we are transferring power from Washington, D.C., and giving it back to you, the people.

[9] For too long, a small group in our nation's capital has reaped the rewards of government while the people have borne the cost.

[10] Washington flourished, but the people did not share in its wealth.

[11] Politicians prospered, but the jobs left and the factories closed.

[12] The establishment protected itself, but not the citizens of our country.

[13] Their victories have not been your victories.

[14] Their triumphs have not been your triumphs.

[15] And while they celebrated in our nation's capital, there was little to celebrate for struggling families all across our land.

[16] That all changes starting right here and right now because this moment is your moment, it belongs to you.

[17] It belongs to everyone gathered here today and everyone watching all across America.

[18] This is your day.

[19] This is your celebration.

[20] And this, the United States of America, is your country.

[21] What truly matters is not which party controls our government, but whether our government is controlled by the people.

[22] January 20th, 2017, will be remembered as the day the people became the rulers of this nation again.

[23] The forgotten men and women of our country will be forgotten no longer.

[24] Everyone is listening to you now.

[25] You came by the tens of millions to become part of a historic movement, the likes of which the world has never seen before.

[26] At the center of this movement is a crucial conviction that a nation exists to serve its citizens.

[27] Americans want great schools for their children, safe neighborhoods for their families, and good jobs for themselves.

[28] These are just and reasonable demands of righteous people and a righteous public.

[29] But for too many of our citizens, a different reality exists: mothers and children trapped in poverty in our inner cities; rusted-out factories scattered like tombstones across the landscape of our nation; an education system flush with cash, but which leaves our young and beautiful students deprived of all knowledge; and the crime and the gangs and the drugs that have stolen too many lives and robbed our country of so much unrealized potential.

[30] This American carnage stops right here and stops right now.

[31] We are one nation and their pain is our pain.

[32] Their dreams are our dreams. 
[33] And their success will be our success.

[34] We share one heart, one home, and one glorious destiny.

[35] The oath of office I take today is an oath of allegiance to all Americans.

[36] For many decades, we've enriched foreign industry at the expense of American industry; subsidized the armies of other countries, while allowing for the very sad depletion of our military.

[37] We've defended other nations' borders while refusing to defend our own.

[38] And spent trillions and trillions of dollars overseas while America's infrastructure has fallen into disrepair and decay.

[39] We've made other countries rich, while the wealth, strength and confidence of our country has dissipated over the horizon.

[40] One by one, the factories shuttered and left our shores, with not even a thought about the millions and millions of American workers that were left behind.

[41] The wealth of our middle class has been ripped from their homes and then redistributed all across the world.

[42] But that is the past.

[43] And now, we are looking only to the future.

[44] We assembled here today are issuing a new decree to be heard in every city, in every foreign capital, and in every hall of power.

[45] From this day forward, a new vision will govern our land.

[46] From this day forward, it's going to be only America first, America first.

[47] Every decision on trade, on taxes, on immigration, on foreign affairs will be made to benefit American workers and American families.

[48] We must protect our borders from the ravages of other countries making our products, stealing our companies and destroying our jobs.

[49] Protection will lead to great prosperity and strength.

[50] I will fight for you with every breath in my body and I will never ever let you down.

[51] America will start winning again, winning like never before.

[52] We will bring back our jobs.

[53] We will bring back our borders.

[54] We will bring back our wealth.

[55] And we will bring back our dreams.

[56] We will build new roads and highways and bridges and airports and tunnels and railways all across our wonderful nation.

[57] We will get our people off of welfare and back to work, rebuilding our country with American hands and American labor.

[58] We will follow two simple rules; buy American and hire American.

[59] We will seek friendship and goodwill with the nations of the world, but we do so with the understanding that it is the right of all nations to put their own interests first.

[60] We do not seek to impose our way of life on anyone, but rather to let it shine as an example.

[61] We will shine for everyone to follow.

[62] We will reinforce old alliances and form new ones and unite the civilized world against radical Islamic terrorism, which we will eradicate from the face of the Earth.

[63] At the bedrock of our politics will be a total allegiance to the United States of America, and through our loyalty to our country, we will rediscover our loyalty to each other.

[64] When you open your heart to patriotism, there is no room for prejudice.

[65] The bible tells us how good and pleasant it is when God's people live together in unity.

[66] We must speak our minds openly, debate our disagreements honestly, but always pursue solidarity.

[67] When America is united, America is totally unstoppable.

[68] There should be no fear.

[69] We are protected and we will always be protected.

[70] We will be protected by the great men and women of our military and law enforcement.

[71] And most importantly, we will be protected by God. 
[72] Finally, we must think big and dream even bigger.

[73] In America, we understand that a nation is only living as long as it is striving.

[74] We will no longer accept politicians who are all talk and no action, constantly complaining, but never doing anything about it.

[75] The time for empty talk is over.

[76] Now arrives the hour of action.

[77] Do not allow anyone to tell you that it cannot be done.

[78] No challenge can match the heart and fight and spirit of America.

[79] We will not fail.

[80] Our country will thrive and prosper again.

[81] We stand at the birth of a new millennium, ready to unlock the mysteries of space, to free the earth from the miseries of disease, and to harness the energies, industries and technologies of tomorrow.

[82] A new national pride will stir ourselves, lift our sights and heal our divisions.

[83] It's time to remember that old wisdom our soldiers will never forget, that whether we are black or brown or white, we all bleed the same red blood of patriots.

[84] We all enjoy the same glorious freedoms and we all salute the same great American flag.

[85] And whether a child is born in the urban sprawl of Detroit or the wind-swept plains of Nebraska, they look up at the same night sky, they will their heart with the same dreams, and they are infused with the breath of life by the same almighty creator.

[86] So to all Americans in every city near and far, small and large, from mountain to mountain, from ocean to ocean, hear these words.

[87] You will never be ignored again.

[88] Your voice, your hopes, and your dreams will define our American destiny.

[89] And your courage and goodness and love will forever guide us along the way.

[90] Together, we will make America strong again.

[91] We will make America wealthy again.

[92] We will make America proud again.

[93] We will make America safe again.

[94] And yes, together we will make America great again.

[95] Thank you.

[96] God bless you.

[97] And God bless America.

[98] Thank you.

[99] God bless America. 